\title{
Документы Национального архива Республики Тыва по культурному строительству Тувинской Народной Республики
}

\author{
Марьятта М. Бадыргы \\ Национальная библиотека им. А. С. Пушкина Республики Тыва, Российская Федерация, \\ Белекмаа В. Мунге \\ Национальный архив Республики Тыва, Российская Федерация
}
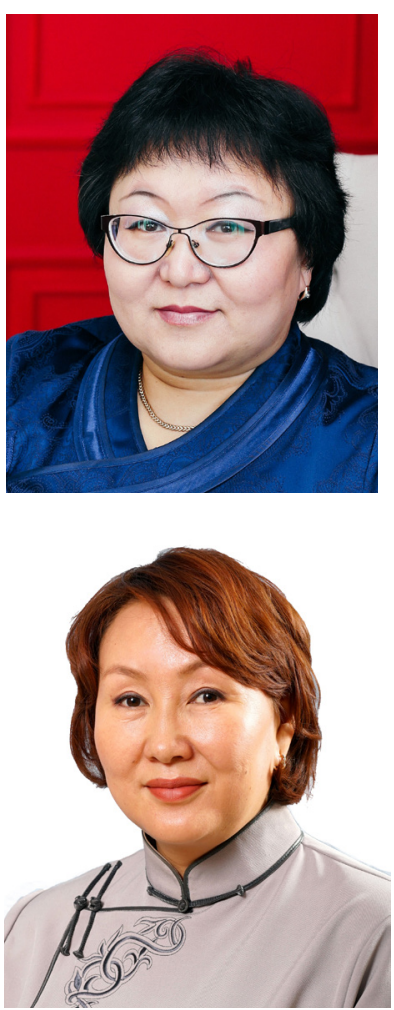

В статье проанализирован состав архивных документов Национального (до 07.04.2020 г. - Государственного) архива Республики Тыва времени Тувинской Народной Республики с 1930 по 1942 г2., которые связаны с управленческими мерами в области культуры и культурной политики. В культурную политику также входили и вопросы здравоохранения, идеологии.

Историография темы представлена широко, однако не все архивные фонды освоены историками. В научный оборот вводятся данные документов, не получивщих достаточного отражения или совсем не использованных, - фондов 93, 102, 114, 144. Описан состав каждого фонда, характеристики и особенности документов. Анализ документов позволил выяснить неизвестные факты культурной жизни периода ТНР, сопоставить их с данными, приведенными в исторических публикациях.

Документы свидетельствуют о том, что молодая республика ставила перед собой задачи по «окультуриванию» нации в самые сжатые сроки. С данной задачей ТНР справилась при помощи СССР и с применением уже апробированных типичных на территории всей СССР форм работы и копированием методов реформирования. Фиксированные в документах факты и меры позволяют делать вывод о внушительных результатах в вопросах культурного строительства.

Ключевые слова: Тувинская Народная Республика; архивный документ; культурное строительство; история Тувы; Тува; тувинская культура; Государственный архив Республики Тыва; Национальный архив Республики Тыва

\section{Для цитирования:}

Бадыргы М. М., Мунге Б. В. Документы Национального архива Республики Тыва по культурному строительству Тувинской Народной Республики // Новые исследования Тувы. 2020, № 2. C. 145-164. DOI: www.doi.org/10.25178/ nit.2020.2.10

Бадыргы Марьятта Маадыр-ооловна - ученый секретарь Национальной библиотеки им. А. С. Пушкина Республики Тыва. Адрес: 667000, Россия, г. Кызыл, ул. Ленина, д. 21. Тел.: +7 (913) 357-14-76. Эл. адрес: 89233805832@mail.ru ORCID ID: 0000-0002-4100-2198

Мунге Белекмаа Владимировна - директор Национального архива Республики Тыва. Адрес: 667000, Россия, г. Кызыл, ул. Кечил-оола, д. 91. Тел.: +7 (923) 262-89-91. Эл. адрес: mungeb@me.com

ORCID ID: 0000-0002-4432-4395

Badyrgy Maryatta Maadyr-oolovna, Academic Secretary, A. S. Pushkin National Library of Republic of Tuva. Postal address: 21 Lenin St., 667000 Kyzyl, Russia. Tel.: +7 (913) 357-14-76. E-mail: 89233805832@mail.ru

Munge Belekmaa Vladimirovna, Director, National Archives of the Republic of Tuva. Postal address: 91 Kechil-ool St., 667000, Kyzyl, Russia. Tel.: +7 (923) 262-89-91.E-mail: mungeb@me.com 


\title{
“Cultural Upbuilding” in People's Republic of Tuva in documents preserved at National Archives of Republic of Tuva
}

\author{
Maryatta M. Badyrgy \\ A. S. Pushkin National Library of Republic of Tuva, Russian Federation, \\ Belekmaa V. Munge \\ National Archives of the Republic of Tuva, Russian Federation
}

\begin{abstract}
Our study makes use of a bulk of documents from the National Archives of Republic of Tuva (prior to 07.04.2020 known as the State Archives) to examine specific features of "cultural upbuilding" in People's Republic of Tuva (PRT) from 1930 to 1942. The fonds in question are related to administrative measures in the fields of cultural policy, healthcare and ideology.

The historiography of the topic is quite well-developed, but there still remain some archival fonds which historians have not covered. The article for the first time introduces a number of documents from ff. 93, 102, 114, 144 which have not received an adequate level of interpretation or never used by anyone. We describe the composition of the fond, as well as provide some details of the documents. Analyzing the documents helped discover some unknown facts of cultural life under PRT, and compare them with the data found in historical research.

Documents reveal that the young republic was seriously focused on "cultural upbuilding" among the nation in the shortest possible terms. PRT achieved that goal with the help of the USSR, by using the forms and methods of work already tested throughout the USSR and copying the USSR reform policies. Many of the administrative choices of the young state appear to have great historical potential from present-day perspective, some ideas being relevant up to present day.
\end{abstract}

Keywords: People's Republic of Tuva (PRT); archival documents; cultural upbuilding; history of Tuva; Tuva; Tuvan culture; State Archives of the Republic of Tuva; National Archives of the Republic of Tuva

\section{For citation:}

Badyrgy M. M. and Munge B. V. “Cultural Upbuilding” in People’s Republic of Tuva in documents preserved at National Archives of Republic of Tuva. The New Research of Tuva, 2020; 2: 145-164. (In Russ.). DOI: www.doi.org/10.25178/nit.2020.2.10

\section{Введение}

1930-1940-е годы в Тувинской Народной Республике (ТНР), как и почти во всей Советской России, осуществлялась определенная культурная политика, которая заключалась в скорейшем переходе от патриархально-феодальных к социалистическим отношениям; преодолении вековой культурной отсталости, ликвидации безграмотности населения, правильном использовании природных ресурсов, создании системы светского образовании и народной интеллигенции. Культура наряду с такими отраслями, как экономика, сельское хозяйство, промышленность, транспорт и связь, строительство, торговля, являлась важной отраслью народного хозяйства и жизнеобеспечения. Соответственно, вопросы культурного строительства, культурной революции оставались приоритетной целью молодого тувинского государства.

В настоящее время интерес к истории создания ключевых учреждений культуры Тувы возрастает в связи с отмечающимися ежегодно юбилеями того или иного учреждения, а также грядущим в 2021 г. 100-летием со дня образования Тувинской Народной Республики. В связи с этим, актуальными остаются вопрос освещения, обнародования архивных документов для научного знания, социальной практики, сравнительного анализа этапов столетнего развития Республики Тыва.

В фондах Национального архива Республики Тыва (Государственного архива Республики Тыва, ГА PT) ${ }^{1}$ имеется большое количество документов, отражающих процесс культурного строительства ТНР.

${ }^{1}$ В связи с тем, что переименование архива пришлось на период предпечатной подготовки статьи (7 апреля 2020 г.) далее мы сохраняем в тексте старое название "Государственный архив Республики Тыва" и аббревиатуру "ГА РТ". - peд.

Editors' note: Since the Archives was renamed while editorial work on the article was already under way (April 7, 2020), we have preserved at some places the institution's old name - "State Archives of the Republic of Tuva". 
Однако богатство архивных материалов периода ТНР еще не до конца освоено исторической наукой. Своих исследователей ждут документы о культурном строительстве ТНР в фондах ГА РТ №№ 108, 109, $113,114,118,231,144$, которые не введены еще в научный оборот, несмотря на их доступность для исследователей.

Целью нашего исследования стал анализ состава архивных документов времени ТНР и выделение из них тех, которые связаны с управленческими мерами в области культуры и культурной политики. Нами изучены материалы, решения, постановления, резолюции и пр. документы Тувинской НародноРеволюционной Партии (ТНРП), Великого Хурала, Малого Народного Хурала (Хурулдана) ТНР, Совета министров ТНР из фондов ГА РТ №№ 1, 92, 93, 100, 102, 112, 114, 120 и 139.

При подборе документов авторы постарались затронуть все направления сферы культуры Тувы: из истории становления тувинского театра, культурно-досуговой деятельности, музейного, библиотечного, ахивного дела, кино и печати.

Новизна предлагаемой статьи заключается также во введении в научный оборот данных архивных документов, не получивших достаточного отражения или совсем не использованных - фондов 93, 102, 114,144 . Фокусирование внимания на содержательно-стилистических особенностях архивных документов позволяет современному исследователю погрузиться в эпоху ТНР, ощутить ее особую атмосферу, чрезвычайно интересную с позиции вековой исторической дистанции. С этой же целью основной текст статьи представляет документы в хронологической последовательности (с 1930 по 1942 гг.).

\section{Историография вопросов культурного строительства}

Вопросы культурного строительства 1920-1940-х гг. России и ее регионов довольно хорошо освещены в работах культурологов, историков, философов. Публикации, выходившие в советское время (1940-1990 гг.) носили ярко выраженный идеологический смысл, в котором отмечалась прогрессивность реформ коммунистической партии (М. П. Ким, А. И. Арнольдов, В. Е. Давидович, Ю. А. Жданов, Э.С. Маркарян и др.). Работы современных исследователей постсоветского времени (П. Штомпка, А. С. Ахиезер, Н. И. Лапин, Н. Н. Козлова, В. А. Красильщиков, Л. И. Новикова, И. Н. Сиземская, Ч. К. Ламажаа и др.) уже стремятся к объективному рассмотрению, с перечислением как положительных, так и отрицательных сторон в культурной политике.

Непосредственно об особенностях культурного строительства в Советской России 1920-1930-х гг. пишет А. В. Костина (Костина, 2009). Автор рассматривает первое послереволюционное десятилетие как время интенсивного развития активно-личностного начала в культуре с доминированием массовизированного, подчиненного стратегиям управления извне индивида.

Целый ряд исследований посвящены культурному развитию в период 1920-1940 гг. в разных регионах страны, в том числе: Дагестане (Богатырева, 2009), Северной Осетии (Гобети, 2009), Кабардино-Балкарии (Шизбухова, 2009), Дальнем Востоке (Белоглазова, 1992), Восточном Забайкалье (Пряженникова, 2011), Бурятии (Цыренова, 2012), Адыгее (Кагазежев Р., Кагазежев Б. 2013) и др. Авторы в своих работах показали не только положительные стороны и грандиозные достижения этого периода - создание общедоступного (бесплатного) образования и медицины, национальной письменности, формирование национальной, культурной, творческой и научной интеллигенции, но и негативные последствия, связанные с преобладанием советской идеологической детерминанты в сфере культуры.

Если у большинства российских и региональных работ по теме культурного строительства отсчет ведется по годам 1920-1940 годы, то, по мнению Ч. К. Ламажаа, этап «силовой мобилизации» Тувы начинается с 1930-х годов - с VIII съезда ТНРП 1929 г. и приходом к власти С. К. Тока, выпускника КУТВа (Ламажаa, 2011). Курс, принятый С. Токой, был отражен в пятой Конституции (1930 г.), в котором ТНР была объявлена «государством трудящихся аратских масс, стремящихся на основе диктатуры трудящихся аратских масс к обеспечению некапиталистического развития страны и существления социализма» (Конституции Тувы, 1999: 49). Согласно новой Конституции беднейшие слои общества должны были управлять обществом, кочевое хозяйство должно перейти на оседлость, конфискация имущества в пользу аратов-бедняков, коллективизация, товарищества, госхозы.

Историография вопросов культурного строительства периода самостоятельной государственности Тувы представлена достаточно широко. Культурному строительству Тувинской Народной Республики в коллективном исследовании «История Тувы» (II том) посвящена глава V «Культурное развитие ТНР» (История Тувы, 2007: 243-314). Коллективом авторов были использованы архивные документы Цен- 
трального государственного архива Республики Тыва (ЦГА РТ, ныне - ГА РТ): ф. 1, оп. 1; ф. 33, оп. 1, д. 14; ф. 92, оп. 1, дд. 29, 352; ф.100, д. 39; ф.144, оп. 2; ф. 689, оп. 1; Центра архивных документов партий и общественных организаций (ЦАДПОО ЦГА РТ, ныне - ГА РТ ФП): ф. 1, оп. 1, дд. 124, 244, 290, 621, 784, 930, 1397, 1447, 1581, 1793, 2063, 2191, 2358, 2435, 2976; ф. 136, оп. 1.

Различные архивные документы, связанные с процессами культурного строительства в Туве периода ТНР, также нашли отражение в научных разработках исследователей советского и постсоветского времён:

- «Перепись населения и хозяйства Тувы 1926 г.» (ЦГА РТ, ф. 144, оп. 13, д. 17) - Ю. Л. Аранчына (Аранчын, 1982),

- ЦГА РТ, ф. 115, оп. 1, д. 24; ф. 92, оп. 1, д. 352; ф. 123, оп. 2, д. 60 - О. М. Хомушку (Хомушку, 1998),

- ЦГА РТ, ф.1, д. 170 - М. Х. Маннай-оол (Маннай-оол, 2001),

- ЦГА РТ, ф. 1, оп. 1, дд. 69, 583, 1581 - А. К. Кужугет (Кужугет, 2006),

- ГА РФ, фр.-5446, оп. 12 а, д. 980; РГАСПИ. ф. 495, оп. 153, д. 3; ф. 508, оп. 3, д. 5; ф. 495, оп. 153, д. 3 ; ф. 508, оп. 3, д. 5 - И. В. Отрощенко (Отрощенко, 2015);

- А. М. Шарап (Шарап, Маадыр, 2018) рассмотрел вопросы концентрации и систематизации документов министерства культуры Тувы с 1921-1944 гг. в фондах Государственного архива РТ, в частности описи № 1, 2 дел постоянного срока хранения на фонд 120 «Министерство культуры ТНР».

Архивные материалы много использованы в монографии Е. К. Карелиной, посвященной истории музыкального искусства в Туве (Карелина, 2009): ЦГА РТ, ф.100, оп. 1, дд. 31, 87, 290; ф.101, оп. 3, дд. 20; ф. 112, оп.1, дд. 360; ф.115, оп.1, дд. 24, 120, 121, 142, 192, 283а, 291, 318; ф.116, оп. 1; ф. 120, оп.1, д. 23; ф. 139, оп.1, дд. 3, 4, 5, 11, 35, 44; ф.188, оп. 1, д. 1; ф. 227, оп. 1, дд. 29, 40; ф. 240, оп. 1, д. 4.

Культурному строительству в ТНР посвящены также работы Л. П. Потапова (Потапов, 1953), С. К. Тока (Тока, 1970), Н. А. Сердобова (Сердобов, 1971). Очевидно, у авторов-современников ТНР и авторов советских времен нужды в ссылках на архивные документы не было. Так, Л. П. Потапов опирался на собственный полевой материал и как этнограф описывал культурную политику собственной современности. Статья С. К. Тока, главной политической фигуры, самого «архитектора», руководителя и участника культурного строительства ТНР, решала задачи не установления и передачи точной информации с архивного источника, а несла политический посыл. А. Н. Сердобов при написании раздела «Формирование социалистической культуры и быта тувинцев» своей монографии опирался на опубликованные труды ученых и публикации в газетах времен ТНР.

Если авторы советского периода (Ю. Л. Аранчын, А. К. Калзан, С. И. Вайнштейн, Л. П. Потапов, А. Д. Грач, Н. А. Сердобов, Л. В. Гребнев, В. И. Дулов, М. Х. Маннай-оол и др.) отмечают преимущественно положительные стороны прогресса периода ТНР, продиктованные особенностями времени, то современные исследования (Н. М. Моллеров, А. К. Кужугет, В. Ю. Сузукей, Ч. К. Ламажаа, З. К. Кыргыс и др.) стали более разнообразными, объективными. Для установления исторической достоверности и исключения перегибов в оценки исторической ситуации необходимо опираться на документы, хранящиеся в архивах.

Анализ ссылок на архивные материалы в имеющихся публикациях показал, что исследователи более всего работают с документами ГА РТ фондов №№ 1, 92, 100, 115, 120, 139.

\section{Направления культурного строительства Тувинской Народной Республики}

В соответствии с документами ГА РТ периода ТНР под словосочетанием «культурное строительство» подразумевалась довольно широкая область жизни и, соответственно, формулировались задачи по нескольким отраслевым направлениям. В понятие «культурное строительство» вкладывалось не только выстраивание системы культуры в нынешнем понимании, связанном с мышлением, художественной культурой, принятыми нормами поведения, но и все, что можно «культивировать» и что связано с развитием реформирования, цивилизации и прогресса.

ГА РТ, ф. 92 «Совет министров ТНР», оп. 1, д. 54. В нем содержится три документа 1930 г.: Положение секции Учкома ТНР по культурной связи с СССР и Монголией, сведения о деятельности амбулатории и стационара 1-ой государственной больницы ТНР с 1 января 1928 г. по 1 января 1930 г. Тезисы к докладам:

\footnotetext{
${ }^{1}$ РГАСПИ - Российский государственный архив социально-политической истории.
} 
«Современное состояние здравоохранения» и «Задачи культурного строительства в Туве» и материаль для делегации ТНР в СССР» - на 39 листах машинописного текста на русском языке.

Документ под заголовком «Тезисы о задачах культурного строительства в Туве» (лл. 8-22), обозначенный как проект - серьезный документ, перешагивающий, на наш взгляд, пределы формата тезисов. Документ в данном фонде представляет собой программу культурного строительства Тувы, состоящую из нескольких разделов. К сожалению, разработчик (автор) документа не указан. В листе использования документа указаны 3 фамилии: Кашпык-оол (1990 г.), Кужугет (1990) и пользователь 1999 г. (фамилия не читается).

Нельзя не отметить ясность, лаконичность и актуальность формы изложения материала.

В разделе I. «Существующее положение культуровня населения» обозначены низкий культурный уровень нации, причинами которому являются многолетняя эксплуатация империалистов, заинтересованных в сохранении Тувы страной дешевой сырьевой базы для торгового капитала; отсутствие письменности, национальной интеллигенции и др.

Выделены задачи и перспективы культурного строительства в Туве, которые заключались в том числе в подготовке кадров через системы различных курсов с отправкой в Советский Союз и организацией дела народного образования внутри республики; создании национальной письменности, светского образования; строительстве школ и школ-интернатов; издательстве и печати, радиофикации, кинофикации.

В данном деле также содержатся документы Ученого комитета (Учком) и научной экспедиции СССР, организованной в 1930 г. при помощи экспедиции т. Покровского․․ Учком руководил издательством Тувброшюр, общегородской библиотекой, типографией. Структура Учкома указана в деле следующим образом: «1) Минкульт, он же Председатель Учкома - Секретарь ЦК АРП; 2) Секретарь ЦК АРП; 3) Заворг. ЦКК АРП; 4) Секретарь ЦК РСМ и 5) Мининдел» (ГА РТ, ф. 92, оп. 1, д. 54, л. 26).

В введении Учкома находились музей, Комиссия Госписьменности. При Учкоме были созданы три секции: экономическая, историческая и краеведческая (л. 26). Интерес представляет «Положение секции Учкома ТАР по культурной связи с СССР», в котором обозначены цели и задачи, права и обязанности секции, виды помощи Делегации СССР (л. 28). Секция устанавливала и развивала научную и культурную связь со Всесоюзным Обществом Культурной Связи с Заграницей (ВОКС).

Далее в деле имеется документ под заголовком «Вопросы делегации СССР» (лл. 29-34), в котором сформулированы основные виды помощи со стороны СССР за подписями министра культуры Тока и зав. Тувздрава Руденко:

«а) Помощь в подготовке кадров,

б) помощь школьному строительству;

в) помощь радио и киноработе,

г) проработке новой письменности» (ГА РТ, ф. 92, оп. 1, д. 54, л. 29).

Нельзя обойти сформулированные конкретные и приблизительные виды помощи СССР, которые заключались в «1. Плановой и всесторонней постановке изучения природных условий и природных богатств страны, 2. ... хозяйства, быта Республики ..., 3. Помощь проведению переписи. 4. Выделение из книгохранилищ, музейных фондов, документов, экспонатов, литературы и др. материалов (в дубликатах), относящихся к бывшему Урянхаю, к Туве и снабжению ими учкома Тувы; 5. Регулярное снабжение литературой, относящейся к странам Востока из фондов Книжной палаты С.С.С.Р. 6. Помощь (организационная) работе Учкома со стороны научных органов СССР» (ГА РТ, д. 92, оп. 1, д. 54, лл. 33, 34). Большая материальная помощь от СССР ожидалась в лечебном деле: «а) достроить больницу на Джедане (Чадан), б) достроить больницу на Тесенголе (Тес-Хем), в) построить больницы: на В. Кемчике (Хемчике), Шагонаре; г) построить поликлинику в Кызыле, д) построить инфекционную больницу в Кызыле» (ГА РТ, ф. 92, оп. 1, д. 54, л. 34; в скобках здесь и далее курсивом написаны нынешнее названия населенных пунктов. - М. Б., Б. М.).

«Вопросы делегации СССР» завершаются планами о приобретении инвентаря и инструментария; развитии курортного дела с лечением и кумысолечением; устройства общежитий, столовых, бань и больниц.

${ }^{1}$ Покровский Л. Д. - начальник экспедиции НИАНКП (Научно-исследовательской Ассоциации по изучению национальных и колониальных проблем) в Тувинскую Народную Республику 1930 г. с целью проведения научного обследования различных сторон современной хозяйственной, политической и культурной жизни республики, заместитель ректора Коммунистического университета трудящихся Востока (КУТВ). 
Таким образом, министерство культуры являлось ключевым органом, сконцентрировавшим в себе широкие полномочия и преследовавшим великую цель и задачи по переводу Тувы в новое, модернизированное общество (л. 34) (фото 1).

ГА РТ, ф. 114 «Экономический Совет ТНР», оп. 1 , д. 3 содержит документы 1930 г.: 1) Постановления IV сессии Мaлого Хурала ТНР о состоянии и дальнейшем развитии животноводства страны, 2) Доклад министра культуры ТНР на VIII Великом Хурале ТНР С. Тока о задачах культурного строительства и современном состоянии здравоохранения в ТНР, 3) Выступление по докладу экономики ТНР на VIII Великом Хурале ТНР - на 32 листах, язык русский, машинописный текст, дополненный рукописными (предположительно самим С. К. Тока) правками (в деле лл. 1-18 дублируются «Тезисы о задачах культурного строительства ТНР (ГА РТ, ф. 92, оп. 1, д. 54).

Существенно дополняет предыдущие тезисы о культурном строительстве доклад министра по культурным делам ТНР С. К. Тока «Современное состояние здравоохранения в Тувинской Аратской Республике» на 7 Великом Хурулдане (т. е. хурале. - М. Б., Б. М.)

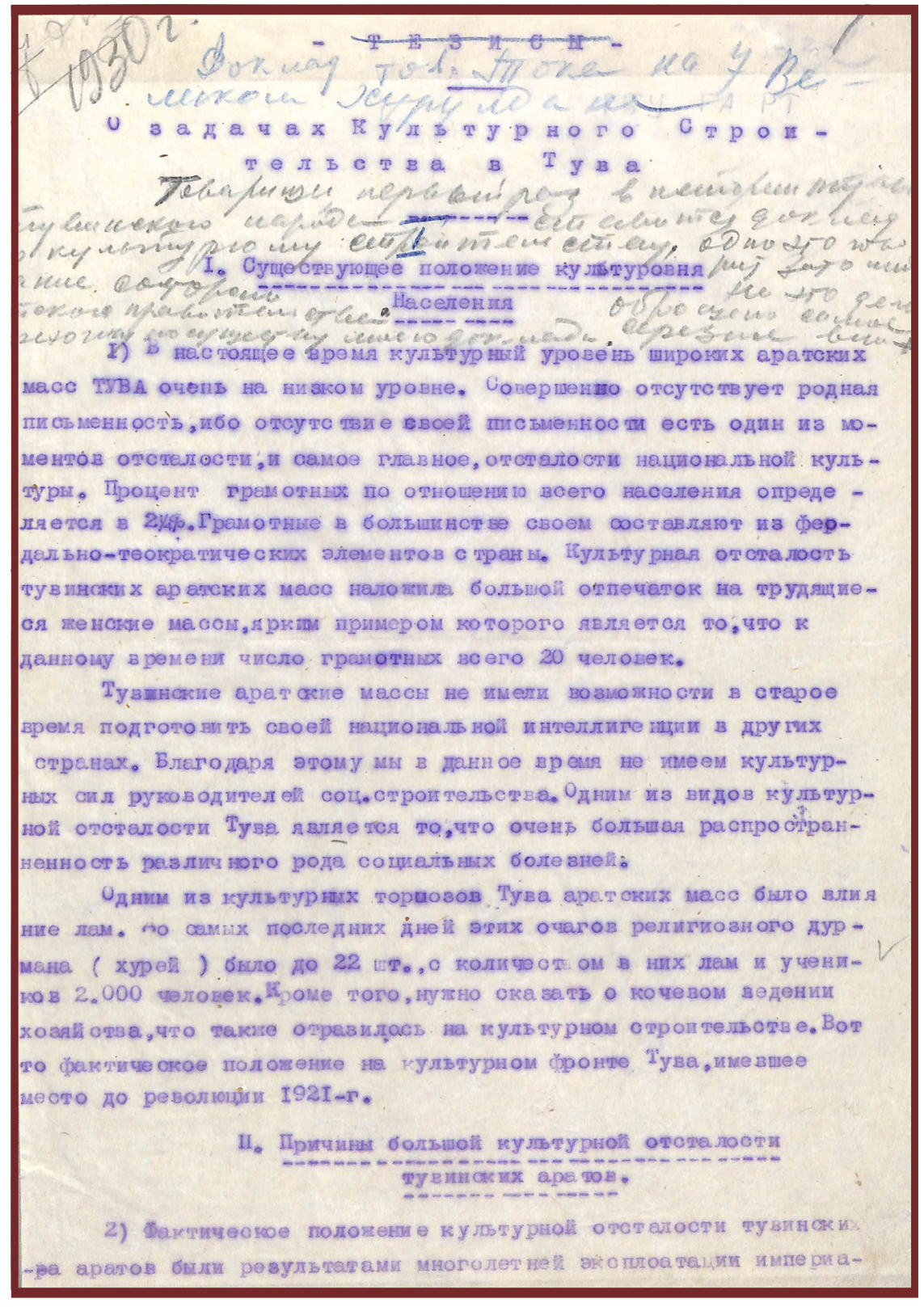

Фото 1. Тезисы о Задачах культурного строительства в Туве, 1930. ГА РТ, ф. 92, on. 1, д. 52, л. 8.

от 13 ноября 1930 г. (л. 19-23). Photo 1. Theses on the tasks of cultural upbuilding in Tuva, 1930. (SA RT, f. 92, op. 1, d. 52, l. 8) В нем содержится информация

об «отрицательных моментах» тибетской медицины, «господствовавшей» в Туве до 1926 г.: «Впервые тувинские аратские массы, благодаря помощи Советского Правительства и народного комиссариата здравоохранения увидели культурную советскую медицину в 1926 году после приезда экспедиции Н. К. (народного комиссариата. - М. Б., Б. М.) Здравоохранения РСФСР» (ГА РТ, ф. 114, оп. 1, д. 3, л. 19).

Свой доклад министр по культурным делам завершает выводами: «Строить социализм араты могут только в том случае, если они сумеют сами быстро освободиться от тяжелого прошлого наследия, т. е. культурной отсталости, с одной стороны, и с другой, - тяжелых социальных заболеваний... Применение европейской медицины самыми широкими аратскими массами есть залог здоровой жизни, а здоровая жизнь есть победа на фронте строительства социализма» (ГА РТ, ф. 114, оп. 1, д. 3, л. 23).

ГА РТ, ф. 92 «Совет министров ТНР», оп. 1, д. 15: «Сведения Минкульта о культурной и издательской работе в ТНР с 1924 2. по 1934 2.» - документ 1934 г. на 6 листах, язык русский, машинописный текст.

Партия и правительство ТНР видели вопросы гигиены и здравоохранения главными составляющими в культурном строительстве, о чем свидетельствует таблица № 11 изданных в 1932 г. в Туве книг 


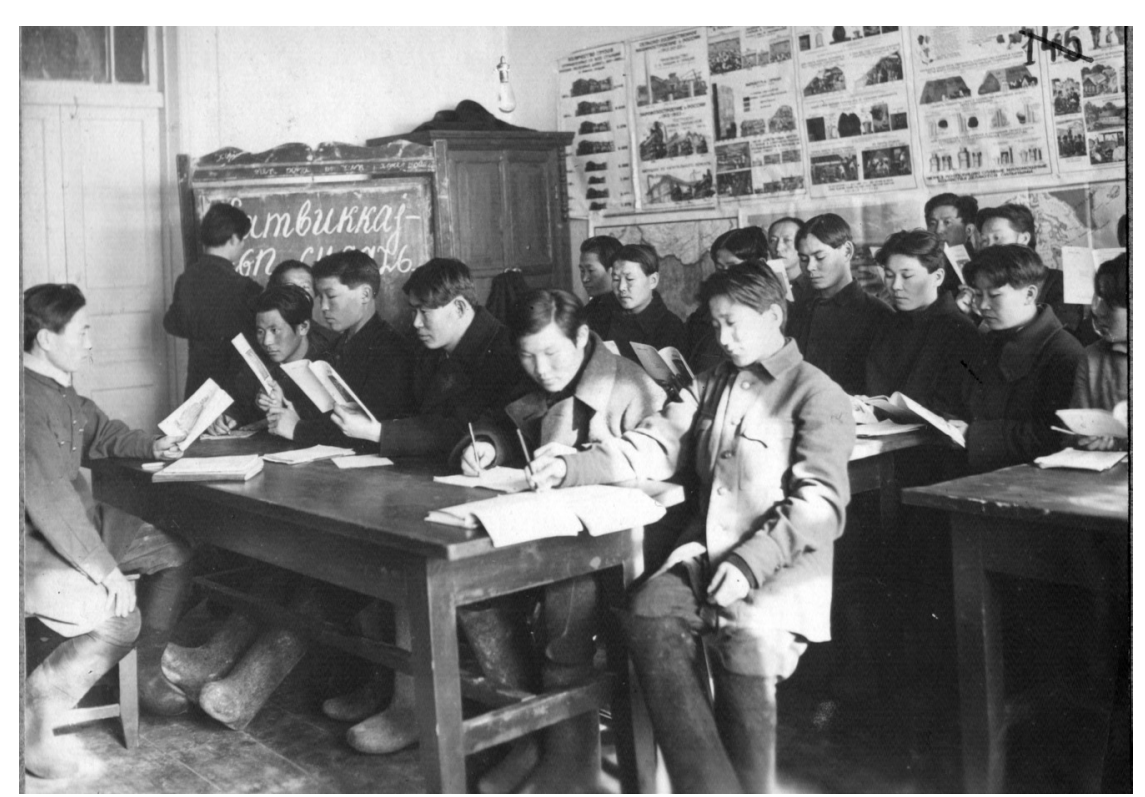

Фото 2. Занятия в кружке по изучению тувинской письменности, 2. Кызыл, 19312.

Из фондов Государственного архива Республики Тыва. Photo 2. Classes of Tuvan writing. Kyzyl, 1930. (SA RT).
«Вопросы народного просвещения Т.Н.Р. (школы, политпросветработа, газеты, издательство)» (л. 6). Документ подписан зам. министра культуры Скворцовой. В перечне изданий имеются такие бюллетени и брошюры по профилактике здорового образа жизни, как «Санитарные мероприятия в худоне» (объем 0,5 листажа $^{1}$ с тиражом в 1000 экз.), «Как уберечься от сифилиса» (таким же объемом, но тиражом в 4000 экз.), «Чесотка» (тираж 3000 экз.), «Гигиена беременности» (тираж 2000 экз.). Все перечисленные брошюры вышли на тувинском языке.

В том же архивном деле имеются сведения с показателями грамотности по данным переписи населения 1933 г. Согласно данной информации, население

в возрасте от 8 до 40 лет делилось на 3 градации: неграмотные, малограмотные и грамотные. Также имеются таблицы о количестве интернатов и их воспитанников на 1932-1933 учебный год; сети политпросвет учреждений по 1929-1934 гг. и тиражей периодической печати в 1931-1933 гг. (газет, журналов, книг). Благодаря приведенным в документе таблицам сегодня у нас есть возможность судить о количественных и качественных показателях издательского дела, а также динамике достижений в ликвидации безграмотности (фото 2).

ГА РТ, ф. 109 «Ученый комитет ТНР», оп. 1, д. 2 «Протокол Ученого комитета ТНР», 1930 г., на 10 листах, яз. русский, машинописный текст.

В деле имеется:

1) Протокол № 2 Заседания президиума Учкома ТАР, состоявшегося в августе 1930 г. (без подписи, л. 1) с предложениями по докладу т. Аюшина «О государственном музее» (л. 2); «О Государственном архиве» (л. 3); «О государственной библиотеке» (л. 4);

2) Протокол І-го Пленума Ученого Комитета Тувинской Аратской Республики, состоявшегося 11 августа 1930 года (л. 5) под председательством тов. Тока, председателя Учкома с участием 18 членов Учкома, приглашенных лиц тт. Богданова, Старкова и Покровского;

3) Резолюция по докладу тов. Арцыбашевой «Пути развития новой тувинской терминологии» (л. 6-7);

4) Протокол №1 Совещания Учено-Консультационной Комиссии Научного отдела от 1 октября (л. 7) под председательством А. В. Цитовича;

5) Протокол № 3 Заседания президиума Ученого Комитета ТАР, состоявшегося в ноябре 1930 г. (лл. 8-9; дата не указана. - М. Б., Б. М.);

6) Протокол Заседания Учкома ТАР, состоявшегося 24/XII-30 г. (л. 10).

Важные поручения о становлении музейного, архивного и библиотечного дел содержатся в проекте «Протокола № 2 заседания Президиума Ученого Комитета ТАР» (август 1930 года) под председательством С. К. Тока. В повестке дня: «Рассмотрение проектов резолюций и практические предложения комиссии по госписьменности и Гиз-а², о Музее, Госархиве и Госбиблиотеке» (ГА РТ, ф. 109, оп. 1, д. 2, л. 1). Предложения трем учреждениям сформулированы в отдельных листах. Так, в предложениях о музее предлагалось ускорить доставку музейных экспонатов от ВОКСа, воспользовавшись пребывани-

${ }^{1}$ Печатный листаж - число печатных листов в отпечатанных экземплярах книги.

${ }^{2}$ Гиз-а, Тув ГИЗ - Государственное издательство ТНР. 
ем тт. Шагдыра и Ермолаева в Москве: «поручить Президиуму Комитета организовать сбор местного краевого материала, предметов культа, закрытых хурей, предметов феодального, родового быта, наметить план для объезда специального человека» (ГА РТ, ф. 109, оп. 1, д. 2, л. 2). Хошунным и сумонным управлениям предлагалось в добровольно-принудительном порядке собрать в музей имеющиеся у них материалы музейного характера в 3-хмесячный срок. Также Президиуму Комитета предложено обратиться в научные учреждения и музеи СССР, в частности в Минусинский и Красноярский музеи с просьбой прислать музейные материалы, могущих интересовать Тувинскую Республику.

В предложениях о Государственном архиве предлагалось «всем государственным учреждениям и общественным организациям как Кызыла, так и хошунам в месячный срок сдать все имеющиеся у них архивы давностью не менее двух лет и в дальнейшем систематически сдавать с госархив все материалы, приведенные в соответствующий порядок по истечении двух оперативных лет». Заведующему Госархивом поручалось обратиться в Улан-Батор, Минусинск, Красноярск и Москву с просьбой прислать в архив все материалы, касающиеся Тувы.

В предложениях о Государственной библиотеке поручалось составить инвентарь библиотеки и десятичный каталог, выписать на имеющиеся средства из СССР и Монголии новейшую политико-экономическую литературу, «приобрести полные комлекты газет «Тувинской Аратской Правды» и «Красного Пахаря», а также всех изданий, вышедших в Кызыле как русских, так монгольских и тувинских. Предложить ТУВ. ГИЗу передавать в библиотеку по 50 экз. всех изданий... Президиуму Ученого Комитета обратиться в научные учреждения СССР, Монголии с просьбой присылки дубликатов научных изданий» (ГА РТ, ф. 109, оп. 1, д. 2, л. 4).

Также решено «целесообразным объединить в одном помещении Госуд. Библиотеку, читальный зал, Гос. Музей и Гос. архив», выделив для этой цели помещение из 3-х комнат (ГА РТ, ф. 109, оп. 1, д. 2, л. 4, п. 8).

ГА РТ, фп-1 «Центральный Комитет Тувинской Народно-Революционной партии (ЦК ТНРП)», оп. 1, д. 1581 «Доклады о культурном строительстве и материалы по партпросвещению, школам и другим отраслям культуры», 1933-1934 гг., на 76 л., языки - тувинский, русский; латинизированный алфавит, машинописный текст.

В таблице на л. 34 содержатся «сведения на 1933 и 1934 гг. о наличии культурной сети по республике (по состоянию на 2 ноября 1934 года)». В табличном виде даны количество школ-интернатов, партшкол, школ приходящих ${ }^{1}$, школ малограмотных ${ }^{2}$, данные о ликпунктах и красных юртах-передвижках, Кызылском педтехникуме и учащихся в них за 1933-1934 гг. в 9-ти хошунах, Кызыле и двух золотых приисках (Карабельдир, Харал), утвержденный заведующим отделом просвещения ЦК АРП Товарищтаем.

Нельзя не заметить снижение показателей по количеству учащихся 1934 г. по сравнению с 1933 г., что говорит о сбое в системе. Так, если в Зун-Кемчикском (т. е. Дзун-Хемчикском) хошуне в 1933 г. количество учащихся школы-интерната насчитывалось 112 человек, то в 1934 г. оно снизилось до 72 чел., то же самое наблюдается в Барун-Хемчикском хошуне: 1933 г. - 91 человек, в 1934 г. - 60 учащихся (фomo 3).

ГА РТ, ф. 93. «Президиум Малого Хурала ТНР», оп. 1, д. 7 «Постановление V-го Великого Хурала ТНР о работе потребительской кооперации. Резолюции Х съезда ТНРП. Постановление XVIII сессии о задачах ТНР на 1937 2. по хозяйственному и культурному строительству”, 1937 г. на 37 л., латинизированный алфавит, машинописный текст на тувинском языке с переводом на русский язык.

Дело содержит резолюцию Х съезда Тувинской Народно-революционной партии (ТНРП) по политическому и организационному отчету ЦК ТНРП от 10 ноября 1936 г., в котором отмечаются достижения за промежуток времени со дня проведения IX съезда ТНРП ТНР (1932 г.).

В области культурного строительства X съезд постановил обеспечить ликвидацию неграмотности среди взрослого аратского населения к 1937 г., для чего добиться создания в каждом сумоне по ликпункту и расширения сети добровольных кружков по изучению письменности, построить по одной зимней и летней школе, обеспечить их соответствующим учительским составом (л. 22, п. 1); создать в

\footnotetext{
${ }^{1}$ Согласно «Тезисам к докладу т.Тостай-оола о Культурном строительстве TAP (к IV сессии Мал. Хурала 1934 г.)» (л. 14) школы приходящие - школы с зачислением детей аратов, постоянно проживающих в школе; а также дети из сумонов, не имеющих у себя зимних школ.

${ }^{2}$ Малограмотным считался тот, который читает от 5 до 15 слов в минуту, умеет писать от 5 до 10 слов в минуту и знает счета до 100 (ГА РТ, ф. 92., оп. 1, д. 15. л. 1).
} 


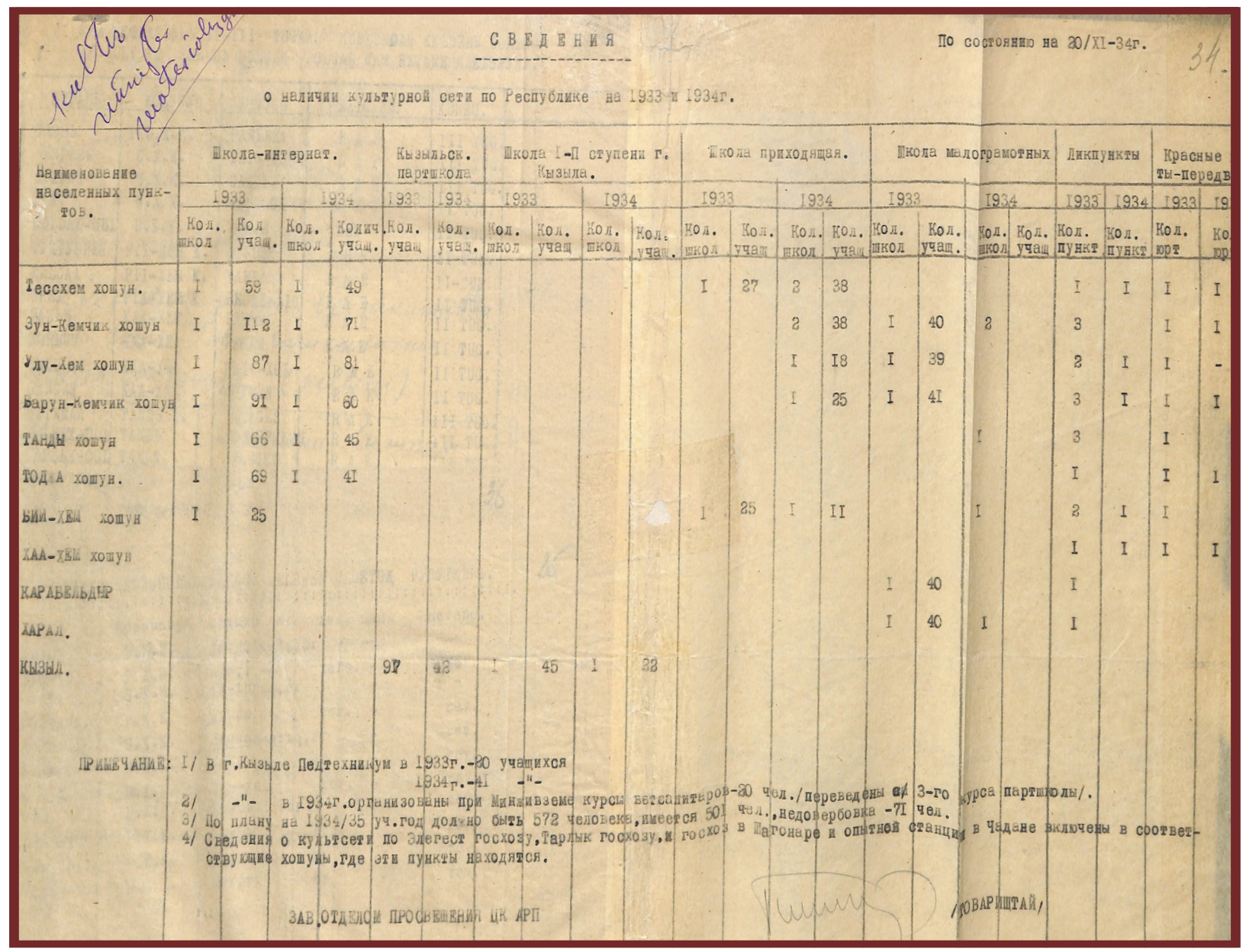

Фото 3. Сведения о наличии культурной сети по республике на 1933 и 1934 г. из доклада ЦК ТНРП о культурном строительстве и материалов по партпросвещению, школам и другим отраслям культуры (1933-1934 г.). (ГА РT, фn-1, on.1, д. 1581, л. 34).

Photo 3. Information about cultural network in the Republic of Tuva for 1933 and 1934. From the report of the Central Committee of the Tuvan People's Revolutionary Party on cultural upbuilding, and from the materials on party education, schools and cultural institutions, 1933-1934 (SA RT, f. П-1, op. 1, d. 1581, l. 34)/

Кызыле в 1936-1937 учебном году учебный комбинат для подготовки национальных специалистов средней квалификации (л. 22, п. 3). Отдельным пунктом поручено всем организациям партии и ревсомола «оказывать всяческое содействие развитию национального искусства и связанным с ним видам культурно-просветительской работы (кино, театр, музей и т. п.) и проводить в худоне массовую работу среди аратов через красные уголки в сумонах, клубы и т. п. по организации выступлений с национальной музыкой, песнями и т. п.» (ГА РТ, ф. 93, оп. 1, д. 7, л. 23, п. 4).

Области здравоохранения, как одной из составляющих культурного строительства ТНР, уделяется немалое внимание. Так, «необходимо обеспечить к 1941 году каждый большой хошун одним врачом, одним фельдшером и не менее чем 2-мя медицинскими юртами-передвижками и малые хошуны (КаХем, Пий-Хем, Танды, Тере-Холь, Тоджа) по одному врачебному пункту и медицинской юрте-передвижке, а также привести в образцовое состояние Кызылскую и Чаданскую больницы, обеспечив в них оказание всех видов лечебной помощи, и курорт Чедыр, доведя в течение ближайших лет его пропускную способность в сезон не менее, чем до 600 человек» (ГА РТ, ф. 93, оп. 1, д. 7, л. 23, п. 5).

В Постановлении Х съезда ТНРП содержится призыв о решительной борьбе с социальными венерическими болезнями путем проведения среди аратов массовой разъяснительно-пропагандистской работы, строгого соблюдения изданных на этот счет законов.

ГА РТ, ф. 92 «Совет министров ТНР», оп. 1, д. 49 «Постановление Совета министров ТНР и отношения Минкульта в Совет министров по вопросам культспорта, соцобеспечения и сведения о количестве аратского населения за 1930-1938 г2.», 1938 г., на 208 л., машинописный текст на тувинском языке, латинизированный алфавит. 
Очередной документ «О культурном строительстве ТНР», подписанный министром культуры Т. Седип-оолом 10 января 1938 г. содержит отчет работы правительства ТНР за 1937 г. и план дальнейшей работы на 1938 г. (л. 1-5). Отмечены: необходимость сохранения и распространения практики организации пионерского лагеря, созданного в 1937 г. и изучения родного края, ее природы. В пункте 12 дается поручение о создании библиотек при кожуунных школах с целью популяризации чтения среди населения (л. 4).

В следующем пункте 13 обозначена важность ведения научно-исследовательской работы на основе материалов исторических памятников и организации в 1938 г. музейного и архивного дел в г. Кызыле. Также намечен план по созданию театрального коллектива с постоянным штатным расписанием, радиокомитета для озвучивания материалов на родном языке и увеличение количества радиоточек в хошунах (л. 4, п.15).

В целях недопущения впредь инфекционных желудочно-кишечных болезней, вспыхнувших в 1937 г. в республике, предлагалось обсудить вопросы санитарно-гигиенической безопасности на конференции врачей, создать комитет и представить на утверждение правительством план профилактических мер. Обозначен план создания 7 хирургических отделений и даны поручения хошунным и сумонным руководителям обеспечить их средствами передвижения и необходимыми продуктами питания. Также запланировано создать (но в документе не было указано, где именно) стационарное лечебно-оздоровительное учреждение для туберкулезных больных (л. 5, пп. 17-20) (фото 4).

Важнейшим событием в истории становления национального искусства стало, пожалуй, решение VIII Великого Хурала об организации Государственного тувинского театра в 1935 г. (ФП-1 ЦК ТНРП, оп. 1, д. 1758 «Резолюции VIII Великого Хурала (на русском языке), принятые 2 июля 1935 года», 1935 г., на 25 листах, яз. русский, машинописный текст, Раздел VII. Народное просвещение. л. 20). С января 1936 г. при учебном комбинате г. Кызыла был создан первый национальный театр-студия с контингентом в 10 человек и открылся театр в Кызыле 25 марта 1936 г. большим концертом.

ГА РТ, ф. 92 «Совет министров ТНР», оп. 1, д. 916 «Постановления Совета Министров ТНР Президиума Малого Хурала и ЦК ТНРП за 1941 год», 1941 г., 268 л., на тувинском языке, латинизированный алфавит.

В постановлении Президиума Малого Хурала и Совета Министров ТНР «О создании Национального оркестра при Госнацтеатре» от 11.01.1941 г., подписанном заместителем председателя Президиума Малого Хурала ТНР Анчымаа и Председателем Совета Министров ТНР Байыр дано поручение «соз-

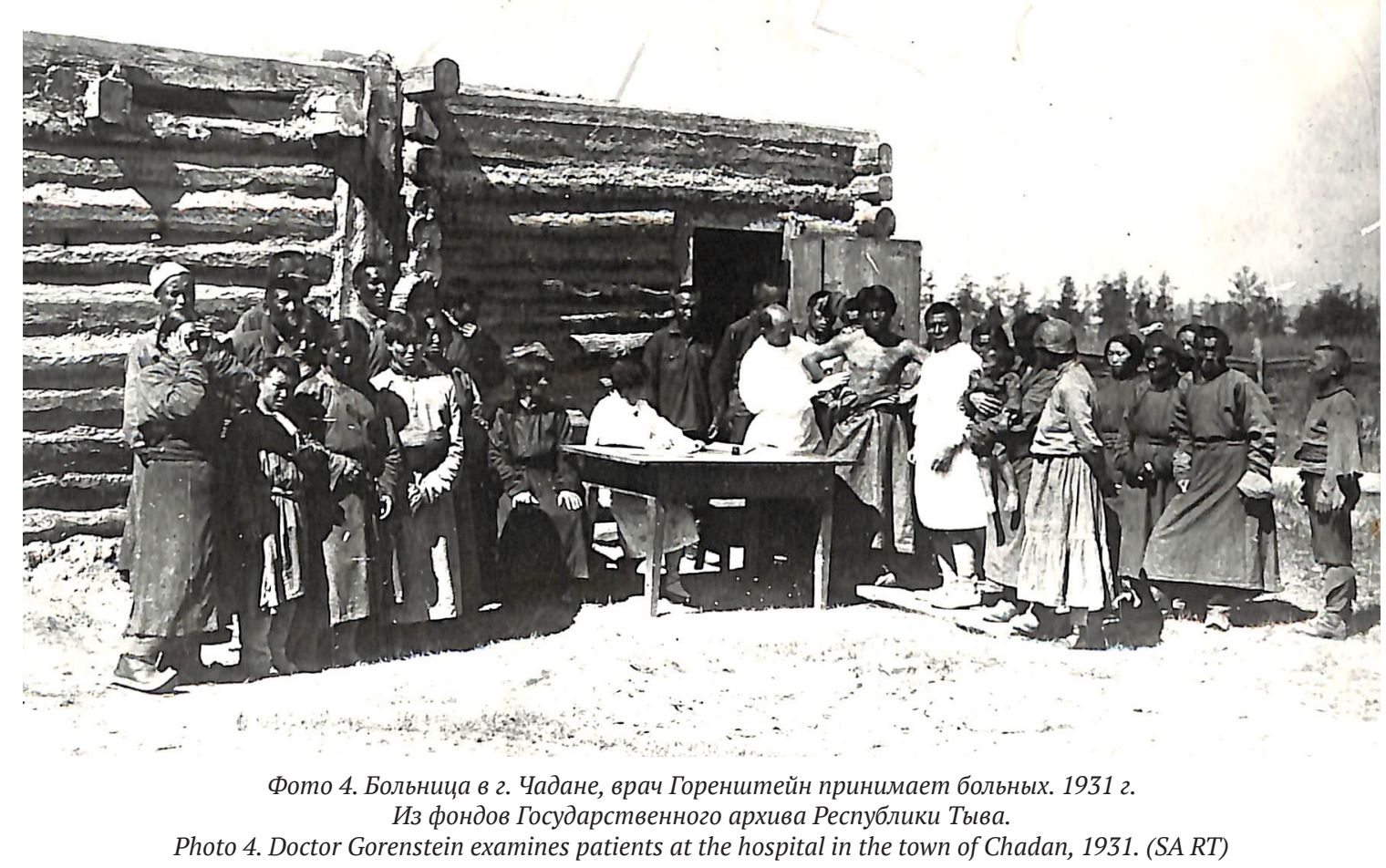




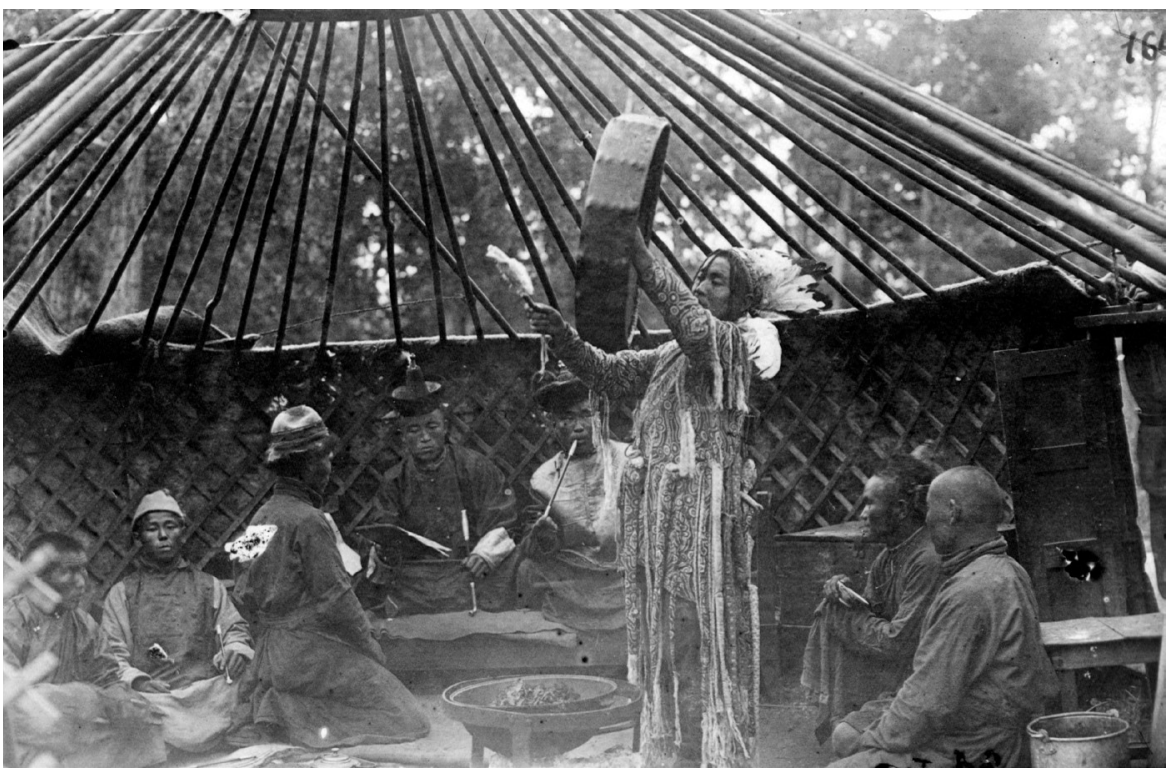

Фото 5. Театральная постановка сцены в юрте нойона. Фото В. П. Ермолаева, г. Кызыл, 1925 г. Из фондов ГА РТ. Photo 5. A scene at the noyon's yurta in a theatrical production. Photo by V. P. Ermolaev, Kyzyl, 1925. (SA RT)

дать оркестр национальных инструментов, для чего Министерству культуры и комитету по искусству организовать конкурсный отбор из числа всесторонне талантливых учащихся объединенной школы г. Кызыла и учащихся 4-5 классов. Директору театра (Сарыг-оолу) поручено представить смету расходов на оплату заработной платой 20 единиц оркестровых музыкантов и приобретение инструментов, а Министерству финансов (Самбуу) изыскать средства на их обеспечение» (ГА РТ, ф. 92, оп. 1, д. 916, л. 12).

ГА РТ, ф. 139 «Государственный музыкально-драматический театр», оп. 1, д. 2 «Постановление ЦК ТНРП о работе государственного музыкально-драматического театра», 1941 г. (предположительно сентябрь), на 5 листах, машинописный текст на русском языке. Содержит проект Постановления Политбюро ЦК ТНРП о работе Государственного музыкально-драматического театра по итогам 1940-1941 учебнопроизводственного года за подписью Генерального Секретаря Центрального Комитета Тувинской Народно-Революционной Партии С. К. Тока.

Из доклада т. Таржаа отмечена большая работа по обслуживанию аратских масс. Так, согласно данному документу, за 6 месяцев (с апреля по сентябрь) в районы выезжали 9 бригад, которые дали 98 выступлений с охватом зрителей около 18000 человек (фото 5). Также отмечены: военный вклад, идея борьбы с гитлеризмом в репертуаре Гостеатра со дня нападения германского фашизма на СССР; работа по обучению национальных кадров театра. Вместе с достижениями указана слабая работа по созданию национального оркестра, невыполнение решения Политбюро ЦК об улучшении жилищных условий артистов театра ${ }^{1}$.

В п. 3 Политбюро ЦК постановляет «Создать оркестр национальных инструментов, для чего закупить набор музыкальных инструментов на 14 человек и пригласить специалиста по национальному оркестру из Бурято-Монгольской АСР сроком на 1 год. Кроме того, начать обучение оркестра игре на русских струнных инструментах (домре, балалайке, мандолине и др.)». (л. 1-2, п. 4) (фото 6).

Ссылка на данный документ имеется в монографии Е. К. Карелиной (Карелина, 2009). Нельзя не согласиться с ее мыслями, что во многом по причине начавшейся войны отпала необходимость дублировать инструменты бурят-монгольского оркестра (там же: 186). В итоге, в театре был создан именно тувинский оркестр во главе с дирижером Р. Мироновичем и мастером К. Тамдыном. Тем самым в эпоху ТНР были заложены основы для формирования оркестра тувинских национальных инструментов в начале XXI века.

В истории зарождения и развития хореографического искусства Тувы имеет важное значение поручение в П. 5 данного Постановления: «В целях создания будущих балетных кадров Гостеатра и развития национального танца, создать при Гостеатре вечернюю хореографическую мастерскую с 2-х летним курсом обучения для детей от 14-15 лет, отпустив для этого на 1941-1942 гг. 4300 акша» (л. 2, п. 5). Исследователь хореограф И. О. Ондар отмечает в этом время о начале выделения из сакральной сферы танцевальных элементов и становлении хореографии как отдельной отрасли тувинского искусства (Ондар, 2016: 79) ${ }^{1}$.

${ }^{1}$ По всей видимости, речь идет о поручении в постановлении Президиума Малого Хурала и Совета Министров ТНР «О создании Национального оркестра при Госнацтеатре» от 11.01.1941 г., хранящемся в предыдущем деле: ГА РТ, ф. 92, оп. 1, д. 916, л. 12. 
В целях развития народного творчества и драматической литературы дано поручение организовать при Комитете по делам искусств методический кабинет по массовой художественной самодеятельности (л. 2, п. 6 «а») и проводить постоянные семинар и консультации для молодых драматургов. (л. 2, п. 6) Также дано поручение городскому самоуправлению о решении вопроса улучшения жилищных условий работников театра. (л. 2., п. 7).

ГА РТ, ф. 120 «Министерство культуры» оп. 1, д. 1 «Положение о Минкульте Тувинской Аратской Республики» (без датировки, без подписи), на 2 л., язык русский, машинописный текст.

В данной папке хранится Положение о Министерстве культуры Тувинской Аратской Республики ${ }^{2}$, на которое был возложен очень широкий спектр полномочий и обязательств (фото 7). Данный орган руководил политико-просветительной, художественной деятельностью; работой по народному просвещению и здравоохранению; государственным издательством (л. 1, раздел I). Министерство осуществляло «руководство всем делом социального воспитания детей и юношества» (л. 1, п. 6), политико-идеологический просмотр печатных произведений и зрелищ (л. 1, об. 2 , раздел II, п. 14). В структуре министерства были сектор соцвоспитания, учебно-методический сектор и сектор политпросветработы, а также отделы Тувгиз, Тувздрав, Тувгоскино (фото 8).

ГА РТ, ф. 100 «Министерство иностранных дел ТНР», оп. 1, д. 31. «План свемки Кинокартины о Туве киноэкспедицией «Совкино». 12.08.1928 г., на 1 листе, яз. русский, рукописный текст.

О попытках фиксирования материалов о Туве в документальных кинолентах свидетельствуют следующие два документа: фонд Министерства иностранных дел ТНР с сопроводительным письмом Представителю Танну-Тувинской Народной Республики г-ну Пунцоку от режиссера Савицкого и оператора Левингтона (фото 8) и Планом съемки кинокартины о Туве киноэкспедицией «Совкино», составленным от 12.08.1928 г. в г. Минусинске. Сам план изложен на одном листе, в котором указаны разделы будущего фильма: «Местоположение края», «Растительный мир», «Животный мир», «Население», «Занятия населения», «Быт» (новый и старый), «Промышленность и торговля».

Пожалуй, данная структура кинокартины стала базовой при создании кинодокументов, киноочерков о Туве, в последствии дополняясь разделами «Культура и искусство», «Туризм». К сожалению, све-

\footnotetext{
${ }^{1}$ Также исследователь в своей работе приводит архивные документы ЦГА РТ ЦАДПОО, ф. 32, оп. 1, д. 64 об учебном плане вечерней хореографической мастерской 1941 г. (Ондар, 2016: 81) и ссылается на ГА РТ, ф. 139, оп. 1. при составлении творческих портретов танцоров периода ТНР, в частности Н. Кысыгбая (там же: 190).

${ }^{2}$ Подготовленный для Председателя Президиума Малого Хурулдана Чульдумом и Председателя Совета Министров Чурмитажи (без подписи).
} 


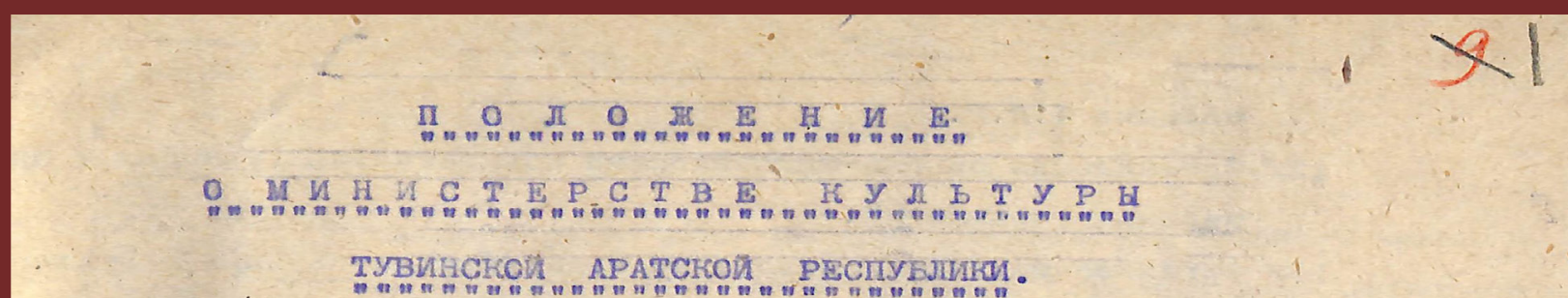

1. - Минстерство Қудвтуры, рувоводит з TAP учебнол, политико.

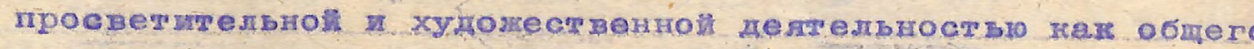

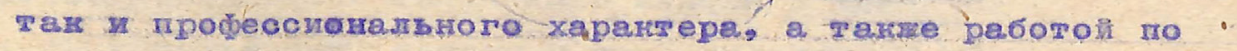
здравоохранения и государственному изданельству В своей раборе. Мнистеротво Культури подииняет ся непосредст вешио Президиуму Малото Хурулдана и Совету Мимистров ТАР.

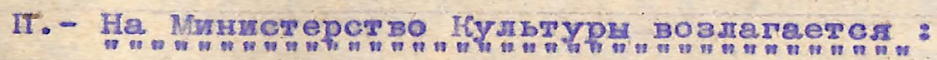

1. Проведение в мизи постановлений Великого Хурулдана, Малого Хурулдана его Президиуме, й Совета Министров по вонросам нарояного лросвещения, здавоохранения и издательства.

2/ Руноводство и содействде местны оргалам власти / Хомунные упразлеж/ в работе по народному просвеиенио и здраноохранения: инспектироване и. инструтировение всех культурно-просветительных учреждении и учрежғ дениl на местах.

3) Изание, пределах предоставленното права, распор ниении, постеновленић, положенй, инструкциі и притазов по вопросал народното просвецения Здравоохранения и издательской работа.-

4 Научнал разработна вопросов народното образования, учет работы нультур

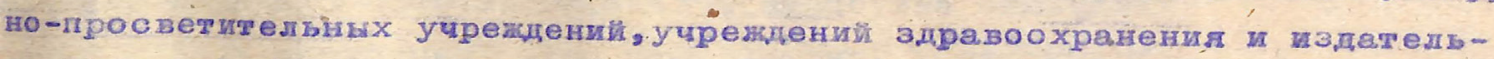
етой работн.

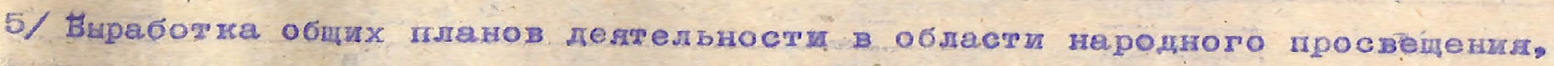
здравоохраненил и издательскон работн.

6/ Руноводство всем делом сониалього воспитания детей и юнонеста, а

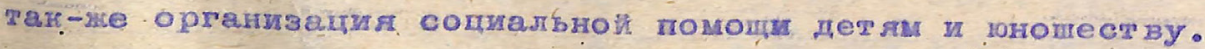

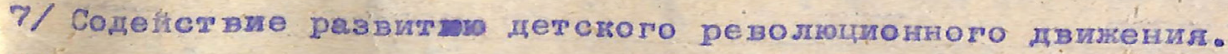

8. Руноводство всеи де́лом профессиональното обрезования

\%) Руноводство повншением твалификации работникөв различних отраслеі труда.

10/ учебно-пуотраминое и методичсское руговодство культурно-просветительный уиремпенлями -

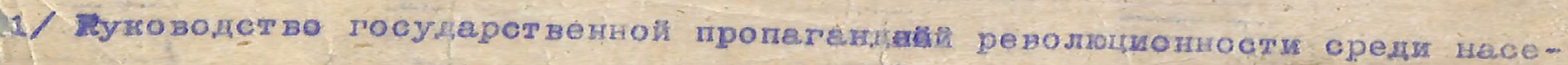

Фото 7. Положение о Министерстве культуры Тувинской Аратской Республики. ГА РТ, ф. 120, оп. 1, д. 1. Photo 7. Regulations on the Ministry of Culture of the Tuva Arat Republic. Photo 7. Regulations on the Ministry of Culture of the Tuva Arat Republic. (SA RT, f.120, op.1, d.1) 


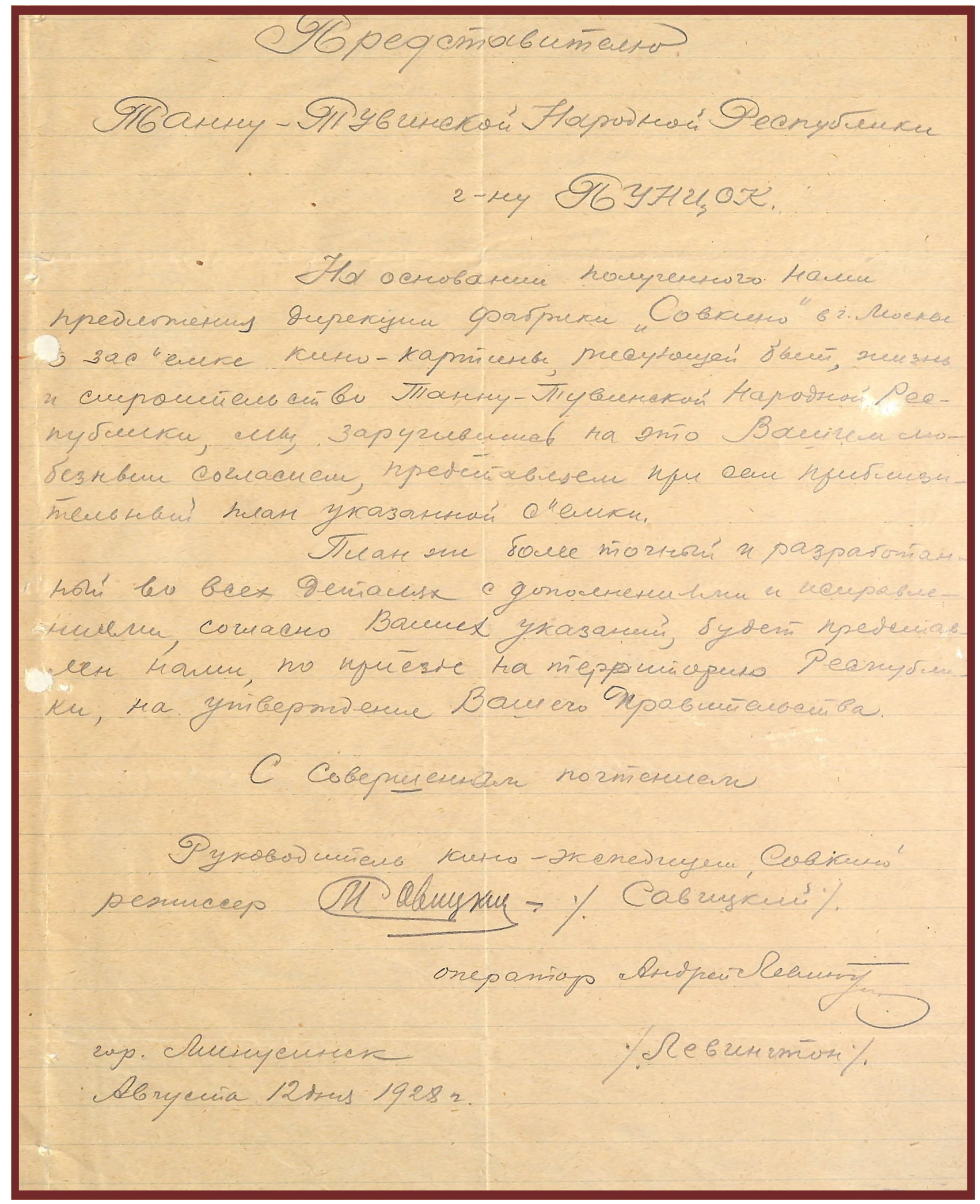

Фото 8. Письмо руководителя кино-экспедиции Савицкого г-ну Пунцоку, Минусинск, 1928 г. ГА РТ, ф. 100, оп. 1, д. 31, л. 31.

Photo 8. Letter from the head of the Savitsky film expedition to Mr. Puntsok. Minusinsk, 1928. (SA RT, f. 100, op. 1, d. 31, l. 31) 
дений о реализации данного проекта пока не найдено ни в документах Госархива РТ, ни в работах исследователей данного периода.

Первый документальный фильм о Туве был создан в 1936 г. под названием «15 лет Тувинской Народной Республики» кинооператорами московской студии «Союзкинохроника». В фондах Госархива РТ хранится также беззвучный документальный фильм «Праздник Тувы» 1936 г.; кинодокументы «Хроника 1941 г.», «Хроника 1943 г.» и звуковой художественно-документальный кинофильм о борьбе и победах революционного тувинского народа «Страна голубой реки» (1941 г.) сценариста Ф. Киселева.

ГА РТ, ф. 100 «Совет Министров ТНР», оп. 1, д. 177 «Договор между «Совмонгтувторгом» $и$ «Твгоскино» о поставке для «Тувгоскино» звуковых и немых кинофильмов для проката их на территории ТАР», 08.05.1938 г., на 4 листах, язык русский, текст машинописный; и д. 258 «Договор между «Тувгоскино» и «Союзкиноторгом» о прокате на территории ТНР художественных, доукментально-художественных, хроникально-документальных фильмов и кино-журналов», 03.01.1941 г. на 6 листах, язык русский, машинописный.

О востребованности и окупаемости в ТНР кинопрокатной деятельности сообщают договора о поставке звуковых и немых кинофильмов для проката их на территории ТНР. В первом случае договор составлен в 1938 г. между Всесоюзным объединением по торговле с Монгольской и Тувинской народными республиками «Совмонгтувторг» и «Тувгоскино» (Хавакчап) и во втором - договор от 3 января 1941 г. между Всесоюзной конторой по кино-экспорту и импорту «Союзторгкино» в г. Москве (т. М. И. Рыжкова) и «Тувгоскино» (Намчак). Договора содержат условия выпуска на экран и пользования фильмами на сумму 26 тыс. и 71 тыс. акша.

ГА РТ, ф. 100 «Минстерство Иностранных Дел ТНР», оп. 1, д. 215 «Переписка НКИД СССР с полномочными Представителями ТНР в СССР и МНР и советскими учреждениями и организациями о культурной связи с заграницей», 17 сентября 1940 г., язык русский, машинописный текст на 34 листах, лл. 18-19.

В письме Председателя Совета Министров и Министра иностранных дел ТНР Баира председателю правления ВОКС тов. Кеменеву о дальнейшем сотрудничестве от 17 сентября 1940 г. имеется просьба об организации радиоконцертов для ТНР, отправке в ТНР советских фильмов, организации в ТНР выставки достижений народного хозяйства СССР и экскурсий для лучших людей ТНР в СССР.

ГА РТ, ф. 120 «Министерство культуры ТНР», оп. 1, Д. 24 «Отчет о работе по созданию первого государственного музея ТНР и деятельности вновь созданного музея с 21 июня 1941 г. по 1 января 1942 года», 1941-1942 г., на 34 листах, язык русский, машинописный текст.

В деле содержится 5 документов: 1) Отчет о работе по созданию 1-го Государственного музея ТНР и деятельность вновь созданного после консервации (1933-1941 гг.) музея с 21 июня 1941 г. по 1 января 1942 г. (лл. 1-20), подписанный директором Государственного музея ТНР Танзын-оолом и научным сотрудников Богатыревым; 2) Производственный план Государственного Музея Тувинской Народной Республики на IV квартал 41 г. (лл. 21-23), 3) Служебная записка «Министру просвещения ТНР. Лопсан-Кендену» от директора музея Танзын-оола от 06.10.1941 г. о принимаемых мерах музея в режиме военного времени (лл. 24-25), 4) Справка «Историко-краеведческие кружки» (лл. 26-27), 5) «Первое задание историко-краеведческого кружка при Госмузее ТНР» и «План работы историко-краеведческого кружка при Государственном музее ТНР» с таблицей «Сведения о наличии древнейших исторических памятников в хошуне сумона» для заполнения секретарем хошунного комитета (лл. 28-34).

Дело содержит ценные материалы по истории становления музейного дела - описание выставок и тематико-экспозиционных планов, отчеты и планы научно-методических, научно-исследовательских, массовых работ, экспедиций и командировок (фото 9); описание вскрытых могильников; опись экспонатов; производственный план. Компетентность и профессионализм разработанных документов свидетельствуют о системном и грамотном подходе специалистов музейного дела, стоявших у истоков создания Государственного краеведческого музея ТНР. Таким образом, нормативно-правовая база музейного дела, его документация изначально были поставлены на очень высоком профессиональном уровне благодаря энтузиастам и немногочисленным музейным работникам того времени.

ГА РТ, ф. 100 «Министерство Иностранных Дел ТНР» оп. 1, д. 244 «Ноты Министерства Иностранных Дел ТНР и СССР, Полпредами МНР в ТНР. Переписка Министерства Иностранных Дел ТНР с учреждениями и организациями СССР по вопросам культурной связи, взаиморасчетах по займам ТНР с СССР и др. платежам ТНР СССР», 1941 г., на 38 листах, язык русский, машинописный текст, лл. 3-4.

О тесном сотрудничестве ТНР с ВОКС свидетельствует письмо председателя ВОКС о согласии на выполнение некоторых работ для краеведческого музея в г. Кызыле (Москва, 22 февраля 1941 г.). ВОКС 


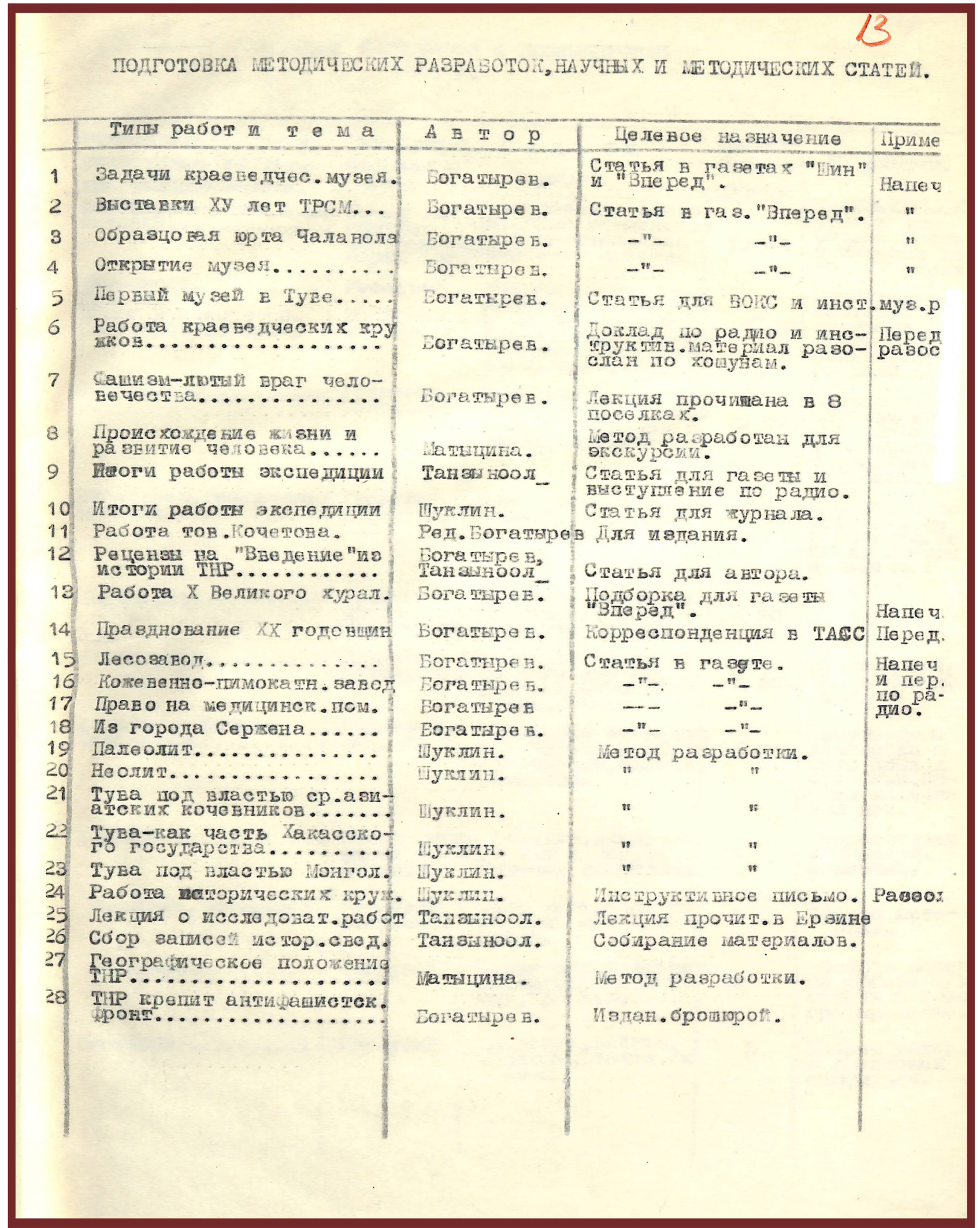

Фото 9. Научные экспедиции и командировки 1941 года (из отчета о работе по созданию 1-го Государственного музея ТНР). ГА РТ, ф. 120, оп. 1, д. 24, л. 13.

Photo 9. Scientific expeditions and business trips of 1941, from the report on the creation of the 1st State Museum of the PRT

(SA RT, f. 120, op. 1, d. 24, l. 13). 
сообщает о готовности Зоологического музея МгУ на выполнение для краеведческого музея в г. Кызыле работы по составлению рабочего плана, подбору фотоматериалов, изготовлении некоторых чучел из материалов Тувинского музея, муляжей основных пород скота и моделей сельскохозяйственных машин. Сообщает также о высылке научно-исследовательским институтом краеведческой и музейной работы литературы по вопросам музейно-краеведческой работы. ВОКС также предлагает представителю Тувинского краеведческого музея поехать в Минусинский музей для получения копий, макетов и фотоснимков, отражающих культуру народов, обитавших на территории Тувинской республики.

О сотрудничестве с ВОКС не только в вопросах организации музейного дела, но и концертно-театральной деятельности свидетельствуют строки: «Что касается вопроса приобретения либретто, альбомов, декораций и тому подобных материалов о театре, то ВОКСу было бы желательно получить более подробную и более точную информацию - какие именно либретто необходимы, какие пьесы и постановки интересуют Кызылский театр. По получении такой информации ВОКС, при посредстве своей театральной секции смог бы организовать консультацию, послать фотоснимки отдельных сцен и действующих лиц, а также некоторые зарисовки» (ГА РТ, ф. 100, оп. 1, д. 244, лл. 3-4).

ГА РТ, ф. 120 «Министерство культуры ТНР» оп. 1, д. 3 «Программа по сельскому хозяйству, программа по физкультуре. Положение о Доме культуры г. Кызыла», без датирования, на 3 листах, язык русский, машинописный текст.

Интерес представляет своего рода техническое задание к типовому двухэтажному зданию Дома культуры. Согласно данному проекту в Доме культуры должны быть сосредоточены культурные учреждения г. Кызыла, а именно: клуб, основные центры физкультуры, кинотеатр, библиотека-читальня, музей, центр санитарного просвещения. При этом в Доме культуры должны быть детская комната, установлено радио. Процитируем часть документа:

«Каменный, двухэтажный Дом культуры вмещает в нижнем этаже:

Зрительный зал на 500 чел. (полтора просвета) для разного рода массовых собраний съездов, конференций, для театральных постановок;

Две комнаты для артистических уборных;

Комната для буфета;

Шесть комнат для кружковых занятий;

Зал физкультуры;

Музей;

Шесть комнат, из которых одна отводится под лаборатории, остальные 5 комнат под зрительновыставочное помещение;

Раздевалка;

Кино-театр/зрит.зал на 500 чел. и фойе. Итого в этом этаже 22 комнаты.

Во втором этаже расположены:

1. Библиотека-читальня (4 комнаты, из которых 2 отводятся для хранения книг, а две другие под громкую и тихую читальню);

2. Детская комната;

3. Канцелярия дирекции;

4. Сектор санитарного просвещения (лекционный зал и 4 комнаты по выставке лаборатории) итого во втором этаже 11 комнат;

5. Построить Дом культуры предложено путем достройки начатого несколько лет тому назад каменного здания под Кызыльский театр (что против “Дома госучреждений”)» (ГА РТ, ф. 120 «Министерство культуры ТНР», оп. 1, д. 3, л. 3).

Интересно то, что идея комплексного размещения всех досуговых учреждений под одной крышей актуальна до сих пор. Подобного рода помещения в настоящее время называются многофункциональными центрами культуры, которые строятся по типовому проекту на федеральные средства. Однако, в Туве подобного культурно-досугового комплекса, где могли бы занять свой досуг и взрослые, и дети, пока что нет.

ГА РТ, ф. 120 «Министерство культуры ТНР» оп. 1, д. 27 «Положения о государственном издательстве, о студии изобразительного искусства, о городском и поселковом клубе ТНР, о культурно-просветительной секции», 1942 г. на 14 листах, язык русский, машинописный текст. Содержит три проекта положений: 1) о культурно-просветительных секциях хошунных малых хуралов трудящихся ТНР от 1942 г.; 
2) о студии изобразительного искусства при министерстве просвещения; 3) о городском и поселковом клубе ТНР.

В положениях прописаны структура, задачи, содержание работы, права и обязанности участников. Интерес представляет последнее из трех положений. Так, широкий спектр задач поставлен перед городскими и поселковыми клубами ТНР: содействие в организации материальной помощи героической Красной Армии, помощь в проведении военно-оборонной работы среди населения, организация физкультурной работы, пропаганда агро-зоотехнических, естественно-научных знаний, антирелигиозная пропаганда, обучение неграмотных и малограмотных, санитарно-просветительная работа, содействие в организации социалистического соревнования и организация культурного отдыха трудящихся путем создания кружков художественной самодеятельности, проведения постановок, концертов, киносеансов, лекций, докладов, бесед, консультаций, массовых игр, вечеров отдыха, прогулок и т. д. Исходя из вышеизложенного, можно удивляться многофункциональности, широте круга тем для пропаганды, универсальности возложенных на работников клуба обязанностей.

\section{Заключение}

Представленные документы Государственного архива Республики Тыва, посвященные вопросам культурного строительства, свидетельствуют о том, что молодая республика ставила перед собой задачи по «окультуриванию» нации в самые сжатые сроки. С данной задачей ТНР справилась при помощи СССР и с применением уже апробированных типичных на территории всей СССР форм работы и копированием методов реформирования. Фиксированные в документах факты и меры позволяют делать вывод о внушительных результатах в вопросах культурного строительства.

Интересно также то, что под культурным строительством правительство не рассматривало только работу с учреждениями культуры, речь шла и о культуре здоровья и пр. вопросах.

Документы фондов 93, 102, 114 свидетельствуют о заложенном фундаменте для расцвета тувинской культуры в отраслях здравоохранения, сельского хозяйства, образования, науки, печати, спорта и, конечно же, культуры. Данные документы не вошли в поле внимания исследователей, и мы рекомендуем их использовать для полноценного анализа исторических событий тех времен.

Многие решения в области культурного строительства видятся с позиции прошедшего времени попрежнему как актуальные и адекватные поставленным перед обществом высоким целям.

Фонды Ученого комитета ТНР 109, оп. 1. д. 2 имеют значение не только для истории становления трех учреждений культуры, но и истории республики, поскольку благодаря созданному в то время фонду архивной структуры сегодня мы имеем возможность оценивать пути развития государственного строя, его экономики, культуры и науки.

\section{СПИСОК ЛИТЕРАТУРЫ}

Аранчын, Ю. Л. (1982) Исторический путь тувинского народа к социализму. Новосибирск : Наука. 337 с.

Белоглазова, С. Б. (1992) Культурное строительство на юге Дальнего Востока СССР 1917-1941 гг. (очерки истории) : автореф. дисс. ... к. и. н. Владивосток. 25 с.

Богатырева, Л. А. (2009) Культурное развитие Дагестана в 20-е годы XX в.: автореф. дисс. ... к. и. н. М. 30 с.

Гобети, 3. Б. (2009) Культурное развитие Северной Осетии в 20-30-ые годы XX века : автореф. дисс. ... к. и. н. Владикавказ. 22 с.

История Тувы (2007) : в 3 т. / под общ. ред. В. А. Ламина. Новосибирск : Наука. Т. 2. 430 с.

Кагазежев, Р. Б., Кагазежев, Б. С. (2013) Вопросы хозяйственного и культурного строительства в Адыгейской автономной области // Вестник Майкопского государственного технологического университета. № 3. С. 10-14.

Карелина, Е. К. (2009) История тувинской музыки от падения династии Цин и до наших дней: исследование. М. : Композитор. 552 с.

Конституции Тувы (1999) / сост. В. А. Дубровский, науч. ред. М. Б. Кенин-Лопсан, отв. ред. К. А. Бичелдей, общ. ред. Ш. В. Кара-оол. Кызыл : Тувинское книжное издательство. 216 с.

Костина, А. В. (2009) Особенности культурного строительства в советской России 20-30-х гг.: к вопросу о субъектном аспекте истории // Знание. Понимание. Умение. № 2. С. 31-40.

Кужугет, А. К. (2006) Духовная культура тувинцев: структура и трансформация. Кемерово: ТИГИ. 319 с. 
Кужугет, А. К. (2017) Центр притяжения. Тувинскому национальному музыкально-драматическому театру 80 лет. Красноярск : ТИГПИ. 232 с.

Ламажаа, Ч. К. (2011) Тува между прошлым и будущим. 2-е изд. СПб. : Алтейя. 368 с.

Маннай-оол, М. Х. (2001) Ученый комитет ТНР и его роль в социально-экономическом и культурном развитии Тувы // Гуманитарные исследования в Туве : сборник научных статей / отв. ред. К. А. Бичелдей, Б. И. Татаринцев, С. М. Биче-оол. М. : РУДН. 336 с. С. 99-106.

Ондар, И. О. (2016) Генезис и трансформация тувинского танца в культуре Тувы : дисс.... канд. культурологии. Кызыл. 203 с.

Отрощенко, И. В. (2015) Языковая политика и культурное строительство в Тувинской Народной Республике [Электронный ресурс] // Новые исследования Тувы. № 2. C. 16-31. URL: https://nit.tuva.asia/nit/article/view/22 (дата обращения: 12.01.2020).

Пряженникова, М. В. (2011) Культурное строительство в Восточном Забайкалье : автореф. дисс. .... к. и. н. УланУдэ. 24 с.

Потапов, Л. П. (1953) Социалистическое переустройство культуры и быта тувинцев // Советская этнография. № 2. С. $72-102$. 482 c.

Сердобов, Н. А. (1971) История формирования тувинской нации. Кызыл : Тувинское книжное издательство.

Тока, С. К. (1970) Торжество ленинской национальной политики КПСС // В братской семье народов / отв. ред. С. К. Тока. Кызыл : Типография управления по печати при Совете Министров Тувинской АССР. 213 с. С. 7-15.

Хомушку, О. М. (1998) Религия в истории культуры тувинцев. М. : Институт этнологии и антропологии РАН. 177 c.

Цыренова, 3. Е. (2012) Политика национально-культурного строительства в Восточной Сибири (1920 - конец 1980-х гг.) // Вестник Бурятского государственного университета. № 7. С. 119-122.

Шарап, А. М., Маадыр, М. С. (2018) Документы Министерства культуры в фондах Государственного архива Республики Тыва // Роль и значение архивов и архивных документов в сохранении исторической памяти народа. Материалы региональной научно-практической конференции, посвященной 100-летию государственной архивной службы России / отв. ред. Б. В. Мунге. Кызыл : Госархив РТ ; ТувГУ. 124 с. С. 89-91.

Шизбухова, Х. Х. (2009) Становление и развитие советской культуры Кабардино-Балкарии в 1920-х гг. : автореф. дисс.... к. и. н. Владикавказ. 21 с.

Дата поступления: 03.03.2020 2.

\section{REFERENCES}

Aranchyn, Yu. L. (1982) Istoricheskii put' tuvinskogo naroda $k$ sotsializmu [The historical path of the Tuvan people to Socialism]. Novosibirsk, Nauka, 337 p. (In Russ.).

Beloglazova, S. B. (1992) Kul'turnoe stroitel'stvo na iuge Dal'nego Vostka SSSR 1917-1941 gg. (ocherki istorii) [Cultural consruction in the south of the USSR's Far East, 1917-1941: essays in history]: Thesis of Diss. ... Candidate of History. Vladivostok. 25 p. (In Russ.).

Bogatyreva, L. A. (2009) Kul'turnoe razvitie Dagestana v 20-e gody XX v. [Cultural development of Dagestan in the 1920s]: Thesis of Diss. ... Candidate of History. Moscow, RUDN. 30 p. (In Russ.).

Gobeti, Z. B. (2009) Kul'turnoe razvitie Severnoi Osetii v 20-30-ye gody XX v [Cultural development of South Ossetia in the 1920s and 1930s]: Thesis of Diss.... Candidate of History. Vladikavkaz. 22 p. (In Russ.).

Istoriia Tuvy [The History of Tuva] (2007): in 3 vols. / ed. by V. A. Lamin. Novosibirsk, Nauka. Vol. 2. 430 p. (In Russ.).

Kagazezhev, R. B. and Kagazezhev, B. S. (2013) Voprosy khoziaistvennogo i kul'turnogo stroitel'stva v Adygeiskoi avtonomnoi oblasti [Issues of economic and cultural upbuilding in Adyghe Autonomous Oblast]. Vestnik Maikopskogo gosudarsvennogo universiteta, no. 3, pp. 10-14. (In Russ.).

Karelina, E. K. (2009) Istoriia tuvinskoi muzyki ot padeniia dinastii Tsin do nashikh dnei [The history of Tuvan music from the fall of the Qing dynasty to the present day]. Moscow, Kompozitor. 552 p. (In Russ.).

Kostina, A. V. (2009) Osobennosti kul'turnogo stroitel'stva v sovetskoi rossii 20-30-kh gg.: k voprosu o sub'ektnom aspekte istorii [The specifics of cultural upbuilding in Soviet Russia of the 1920s and 30s: on subjective aspect of history]. Znanie. Ponimanie. Umenie, no. 2, pp. 31-40. (In Russ.).

Kuzhuget, A. K. (2006) Dukhovnaia kul'tura tuvintsev. Struktura i transformatsiia [The immaterial culture of Tuvans. Structure and transformation]. Kemerovo, KemGUKI. 319 p. (In Russ.)

Kuzhuget, A. K. (2017) Tsentr pritiazheniia. Tuvinskomy natsional'nomy teatru - 80 let [Center of attraction. Tuvan National Music and Drama Theater turns 80]. Krasnoiarsk, TIGPI. 232 p. (In Russ.).

Lamazhaa, Ch. K. (2011) Tuva mezhdu proshlym i budushchim [Tuva between the past and future]. St. Petersburg, Aletheia. 368 p. (In Russ.). 
Mannai-ool, M. Kh. (2001) Uchonyi komitet TNR i ego rol'v sotsial'no-ekonomicheskom razvitii Tuvy [The PTR Academic Committee and its role in socioeconomic and cultural development of Tuva]. In: Gumanitarnye issledovania $v$ Tuve: sbornik nauchnykh statei [Humanities Research in Tuva: collected scholarly articles]. Ed. by K. A. Bicheldei, B. I. Tatarintsev and S. M. Biche-ool. Moscow, RUDN. 336 p. Pp. 102-104. (In Russ.).

Ondar, I. O. (2016) Genezis i transformatsiia tuvinskogo tantsa $v$ kul'ture Tuvy [Genesis and transformation of folk dance in the culture of Tuva]: Diss.... Candidate of Culture study. Kyzyl. 203 p. (In Russ.).

Otroshchenko, I. V. (2015) Iazykovaia politika i kul'turnoe stroitel'stvo v Tuvikskoi Narodnoi Respublike [The language policy and cultural building in the Tuvan People's Republic]. The New Research of Tuva, no. 2, pp. 16-31 [online] Available at: https://nit.tuva.asia/nit/article/view/22 (access date: 12.01.2020).

Priazhennikova, M. V. (2011) Kul'turnoe stroitel'stvo $v$ Vostochnom Zabaikal'e [Cultural upbuilding in Eastern Transbaikalia]: Thesis of Diss.... Candidate of History. Ulan-Ude. 24 p. (In Russ.).

Potapov, L. P. (1953) Sotsialisticheskoe pereustroistvo kul'tury i byta tuvintsev [Socialist restructuring of Tuvan culture and life]. Sovetskaia etnografiia, no. 2, pp. 72-102 (In Russ.).

Serdobov, N. A. (1971) Istoriia formirovaniia tuvinskoi natsii [The history of the formation of the Tuvan nation]. Kyzyl, Tuvan book publisher. 482 p. (In Russ.).

Toka, S. K. (1970) Torzhestvo leninskoi natsional'noi politiki KPSS [The triumph of Leninist national politics of the CPSU]. In: V bratskoi sem'e narodov [In the brotherly family of peoples]. Ed. by S. K. Toka. Kyzyl, Tipografiia po pechati pri Sovete Ministrov Tuvinskoi ASSR. 213 p. Pp. 7-17. (In Russ.)

Khomushku, O. M. (1998) Religiia v istorii kul'tury tuvintsev [Religion in the history of Tuvan culture]. Moscow, Institut etnologii i antropologii RAN. 177 p. (IN Russ.).

Tsyrenova, (2012) Politika natsional'no-kul'turnogo stroitel'stva v Vostochnoi Sibiri (1920 - konets 1980-kh gg.) [Politics of the national cultural upbuilding in Eastern Siberia: from 1920 to the late 1980s]. Vestnik Buriatskogo gosudarstvennogo universiteta, no. 7, pp. 119-122. (In Russ).

Sharap, A. M. and Maadyr, M. S. (2018) Dokumenty Ministerstva kul'tury v fondakh Gosudarstvennogo arkhiva Respubliki Tyva [Documents of the Ministry of Culture in the State Archives of the Republic of Tyva]. In: Rol' $i$ znachenie arhhivov $b$ arkhivnykh dokumentov $v$ istoricheskoi pamiati naroda. [Role and importance of archives and archival documents in historical memory of a people]. Proceedings of the regional research conference devoted to the 100th anniversary of the Archival Service of Russia. Ed. by B. V. Munge. Kyzyl, Gosarhiv RT, TyvGU. 124 p. Pp. 89-91. (In Russ.).

Shizbukhova, Kh. Kh. (2009) Stanovlenie i razvitie sovetskoi kul'tury Kabardino-Balkarii v 1920-kh gg. [The rise and development of Soviet culture in Kabardino-Balkaria in the 1920s] : Thesis of Diss.... Candidate of History. Vladikavkaz. 21 p. (In Russ.).

Submission date: 03.03.2020. 